\title{
Teachers' Sex and Students' Preferences of Teachers' Personality Traits among Selected Public Junior High School in Western Misamis Oriental, Philippines
}

\author{
Dulce Ann Laput Gaid, MSciEd \\ Integrated Developmental School \\ Mindanao State University at Naawan \\ Naawan, Misamis Oriental \\ Philippines \\ Bella Culi Mugot, MST \\ College of Education and Social Sciences \\ Mindanao State University at Naawan \\ Naawan, Misamis Oriental \\ Philippines
}

\begin{abstract}
This study was designed to determine the teachers' sex and students' preferences of teachers' personality traits among selected Public High School. It aimed to determine the significant difference between the teachers' sex and students' preference of teachers' personality traits when grouped to male and female, find out the significant difference between the teachers' sex and students' preference of teachers' personality traits when grouped to year level, and find out the significant difference between the teachers' sex and students' preferences of teachers' personality traits. There were four hundred two (402) male and female students of selected public Junior High School in Western Misamis Oriental, Philippines involved in the study. This study utilized the quantitative descriptive research design. Result showed that both male and female teachers revealed highly significant difference on teachers' personality traits such as fair, democratic, responsive, understanding, kindly, stimulating, original, alert, attractive, and responsible. This study concluded that teachers' sex can affect the students' preferences on teachers' personality traits.
\end{abstract}

Keywords: Sex, teachers' personality traits, year level, Junior High School

\section{Introduction}

An individual starts shaping his personality from birth through his interaction with numerous variables (e.g., family, school, peers). The responsibility of shaping kid's behaviour and future success within that society lies with teachers who are the second parents for the students because students spend a lot of time with their teachers. Thus, teachers are the one who influence the students most (Ozel, 2007). The teachers are highly looked up by the students as their models. This was conceptualized by Bandura (1977) that individuals are more likely to adopt a modelled behaviour if the model is similar to the observer and has admired status and the behaviour has functional value.

Studies reveal that teacher's personality may directly influence learning and engagement or may indirectly influence via an effect upon motivation (Spanjaard, 2009) and influences learning outcome (Heinstrom, 2000). Accordingly, desirable traits of educators have been identified as the need for student-teacher rapport (Granitz, et al., 2009). There are specialized skills and attributes of an effective teacher and the four competencies that must be considered: (1) display of attitudes that foster learning and genuine relationships, (2) sureness and adequacy of knowledge in the subject matter to be taught, (3) command of theoretical knowledge about learning and human behaviour, and (4) control of skills of teaching that facilitate student learning (Ryan and Cooper, 1984).

This was carried out with optimism to give information that would be beneficial to student-teachers, teachers, and school administrators. Teachers' personality traits and sex must be considered in the teaching-learning process for a better learning environment between the students and the teachers. Students' evaluation and perception on their teachers would help improve the teaching-learning process. Their feedbacks and responses are necessary in maintaining genuine teacher-student relationship.

\section{Methodology}

This study used the quantitative descriptive research design. There were four hundred (402) students in the following public secondary schools in Western Misamis Oriental, namely: Lugait National High School, Initao National Comprehensive High School, Laguindingan National High School and Alubijid National Comprehensive High School involved in the study. This study used stratified random sampling to get the respondents. 
The questionnaire was patterned after that of Ryan and Cooper's (1984) description of twelve teacher's personality traits. Each trait was represented by five statements were based on experienced and observation in the classroom teaching-learning process. The questionnaire consisted of 60 items and was divided into three (3) sets (A, B, and C), each of which contained 20 items and was pre-tested. The terms in the statements of the questionnaire which were difficult for the students found to understand were simplified before this was given to the students as respondents from the four selected public high schools.

In each statement, the students rated their male and female teachers based on their perception of which traits and sex they prefer. In the questionnaire, the subjects would rate using the Likert scale: $5=$ strongly agree, $4=$ moderately agree, $3=$ agree, $2=$ disagree, and $1=$ strongly disagree. This study utilized mean and Paired t-test to analyze the data.

\section{Results and Discussion}

Table 1 shows the paired t-test result showing the difference between the teachers' sex and students' preference on teachers' personality traits. It reveals a highly significant difference between the teachers' sex and students' preference personality traits. This means that male students preferred female teachers over male teachers. The female teachers had significantly higher ratings $(p<0.05)$ than male teachers. Female students preferred female teachers over male teachers since the female students gave higher scores to female teachers. Male and female students have the same teacher-sex preferences. They both preferred female teachers than male teachers.

According to Shah and Udgaonkar (2018),out of 75, 44\% (33) of the students preferred ladies as teacher, whereas preference for male teacher was $27 \%$ (20) and $29 \%$ (22) of students were neutral. This observeddifference between preference for ladies and gents was statistically not significant i.e. P $>0.05$. But still many students preferred ladies as teacher and the reasons attributed were, their sincerity, hard work, efforts taken in preparing lectures, politeness and high pitch audible voice quality.

Table 1. Paired t-test results showing the difference between the teachers' sex and students' preferences on teachers' personality traits.

\begin{tabular}{|c|c|c|c|c|c|c|}
\hline $\begin{array}{l}\text { Student } \\
\text { Sex }\end{array}$ & $\begin{array}{l}\text { Teacher } \\
\text { Sex }\end{array}$ & $\begin{array}{l}\text { Mean } \\
\text { Score }\end{array}$ & $\begin{array}{l}\text { Paired Mean } \\
\text { Difference }\end{array}$ & $\mathrm{t}$-value & p-value & Remarks \\
\hline Male & Male & 3.985 & & & & Highly \\
\hline \multirow{3}{*}{ Female } & Female & 4.055 & -0.0706 & -3.758 & 0.000 & Significant \\
\hline & Male & 4.029 & & & & Highly \\
\hline & Female & 4.168 & -0.1385 & -6.488 & 0.000 & Significant \\
\hline
\end{tabular}

Table 2 displays the paired t-test showing the difference between teachers' sex and students' preferences by year level. The Grade 7, Grade 8 and Grade 9 students reveal significantly higher $(\mathrm{p}<0.05)$ scores for female teachers. This means that the Grade 7 - Grade 9 students preferred female teachers than male teachers. Grade 10, on the other hand, do not have teacher-sex preferences. The difference of scores given by the Grade 10 is not significant $(\mathrm{p}>0.05)$.It is further supported by the few students that Grade 7 students rated female teachers highly significant over male teachers this is because mostly preferred female teachers since these group of respondents are prone to extrinsic motivation, meaning their learning outcomes are largely influenced by external factors such as teaching methodologies, peer influences, sex of teacher, teacher's attribute, and the like. Grade 8 and third Grade 9 students rated female teachers higher since these group of students are also extrinsically motivated, their attitudes are influenced by the outside influences including teacher's traits, peers, praise, acquiring good or some type of reinforcement that a teacher or peer might offer. However, Grade 10 students are group of respondents who perceived teacher's not significant, since these students have already experienced much in the high school. Grade 10 students are intrinsically motivated. Hence, these students are motivated to do something because it brings them pleasure, they think it is important, or they feel that learning a lesson is morally significant (Bustos and Espiritu, 1996). 
Table 2. Paired T-test results showing the difference between the teachers' sex and students' preferences of the personality traits by year level.

\begin{tabular}{|c|c|c|c|c|c|c|}
\hline Year levels & $\begin{array}{l}\text { Teacher } \\
\text { Gender }\end{array}$ & $\begin{array}{l}\text { Mean } \\
\text { Score }\end{array}$ & $\begin{array}{c}\text { Paired Mean } \\
\text { Difference }\end{array}$ & t-value & p-value & Remarks \\
\hline Grade 7 & $\begin{array}{c}\text { Male } \\
\text { Female }\end{array}$ & $\begin{array}{l}3.972 \\
4.145\end{array}$ & -0.1727 & -6.443 & 0.000 & $\begin{array}{c}\text { Highly } \\
\text { Significant }\end{array}$ \\
\hline Grade 8 & $\begin{array}{c}\text { Male } \\
\text { Female }\end{array}$ & $\begin{array}{l}3.974 \\
4.069\end{array}$ & -0.0943 & -3.214 & 0.002 & Significant \\
\hline Grade 9 & $\begin{array}{c}\text { Male } \\
\text { Female }\end{array}$ & $\begin{array}{l}3.932 \\
4.040\end{array}$ & -0.1075 & -3.502 & 0.001 & Significant \\
\hline Grade 10 & $\begin{array}{c}\text { Male } \\
\text { Female }\end{array}$ & $\begin{array}{l}4.161 \\
4.194 \\
\end{array}$ & -0.0362 & -1.370 & 0.174 & $\begin{array}{c}\text { Not } \\
\text { Significant }\end{array}$ \\
\hline
\end{tabular}

Table 3 reveals paired t-test result showing the difference between the teachers' sex and students' preferences of teachers' personality traits. The female teachers have higher personality traits scores than male teachers among the four schools. Female teachers are more fair, democratic, responsive, understanding, kindly, stimulating, original, alert, attractive, responsive, steady, and confident than the male teachers.

Personality trait preference scores of male and female teachers have significant differences. Among the 12 personality traits, fair, democratic, responsive, understanding, kindly, original, alert, attractive, responsible were highly significant $(\mathrm{p}<0.05)$ while stimulating, steady and confident traits were significant $(\mathrm{p}<0.05)$ between male and female teachers. A combination of personality traits of male or female teachers is necessary to be able to accomplish all the task and duties. Finally, teachers have to be created in their approaches to instruction to earn the most successful results in educating their students (Marchbanks, 2000). Many educators believe that elementary and secondary teachers require attitudes, knowledge, and skills unique to the teaching profession and many people believe that the teacher's personality is the most critical factor in successful teaching. Almost all educators are convinced of the importance of teacher personality traits and attitudes in the teaching process (Ryan and Cooper, 1984). 
Table 3. Paired T-test results showing the difference between the teachers' sex and students' preferences of teachers' personality traits.

\begin{tabular}{|c|c|c|c|c|c|}
\hline $\begin{array}{c}\begin{array}{c}\text { Personality Trait/Gender of } \\
\text { Teacher }\end{array} \\
\end{array}$ & Score & $\begin{array}{c}\text { Mean } \\
\text { Difference } \\
\end{array}$ & t-value & p-value & Remarks \\
\hline \multicolumn{6}{|l|}{ 1. Fair } \\
\hline Male Teacher & 4.005 & \multirow{3}{*}{-0.1204} & \multirow{3}{*}{-5.533} & \multirow{3}{*}{0.000} & \multirow{3}{*}{$\begin{array}{l}\text { Highly } \\
\text { significant }\end{array}$} \\
\hline & & & & & \\
\hline Female Teacher & 4.126 & & & & \\
\hline \multicolumn{6}{|l|}{ 2. Democratic } \\
\hline Male Teacher & 3.959 & \multirow[b]{2}{*}{-0.1109} & \multirow[b]{2}{*}{-5.531} & \multirow[b]{2}{*}{0.000} & \multirow{2}{*}{$\begin{array}{l}\text { Highly } \\
\text { Significan }\end{array}$} \\
\hline Female Teacher & 4.070 & & & & \\
\hline 3. Responsive & & & & & \\
\hline Male Teacher & 3.938 & \multirow[b]{2}{*}{-0.1353} & \multirow[b]{2}{*}{-5.587} & \multirow[b]{2}{*}{0.000} & \multirow{2}{*}{$\begin{array}{l}\text { Highly } \\
\text { Significan }\end{array}$} \\
\hline Female Teacher & 4.074 & & & & \\
\hline \multicolumn{6}{|l|}{ 4. Understanding } \\
\hline Male Teacher & 4.055 & \multirow[b]{2}{*}{-0.1204} & \multirow[b]{2}{*}{-4.667} & \multirow[b]{2}{*}{0.000} & \multirow{2}{*}{$\begin{array}{l}\text { Highly } \\
\text { Significan }\end{array}$} \\
\hline Female Teacher & 4.176 & & & & \\
\hline \multicolumn{6}{|l|}{ 5. Kindly } \\
\hline Male Teacher & 4.027 & \multirow[b]{2}{*}{-0.1343} & \multirow[b]{2}{*}{-5.401} & \multirow[b]{2}{*}{0.000} & \multirow{2}{*}{$\begin{array}{l}\text { Highly } \\
\text { Significant }\end{array}$} \\
\hline Female Teacher & 4.162 & & & & \\
\hline \multicolumn{6}{|l|}{ 6. Stimulating } \\
\hline Male Teacher & 4.019 & \multirow[b]{2}{*}{-0.0726} & \multirow[b]{2}{*}{-3.400} & & Highly \\
\hline Female Teacher & 4.092 & & & 0.001 & Significant \\
\hline 7. Original & & & & & \\
\hline Male Teacher & 3.955 & -0.1199 & -5.530 & 0.000 & $\begin{array}{l}\text { Highly } \\
\text { Significant }\end{array}$ \\
\hline $\begin{array}{l}\text { Female Teacher } \\
\text { 8. Alert }\end{array}$ & 4.075 & & & & \\
\hline Male Teacher & 4.016 & & & & Highly \\
\hline Female Teacher & 4.114 & -0.0980 & -4.162 & 0.000 & Significant \\
\hline 9. Attractive & & & & & \\
\hline Male Teacher & 3.881 & & & & Highly \\
\hline Female Teacher & 4.034 & -0.1537 & -7.603 & 0.000 & Significant \\
\hline 10. Responsible & & & & & \\
\hline Male Teacher & 4.001 & 00801 & 4073 & 0000 & $\begin{array}{l}\text { Highly } \\
\text { Sionificant }\end{array}$ \\
\hline Female Teacher & 4.082 & & & & \\
\hline 11. Steady & & & & & \\
\hline Male Teacher & 3.990 & & & & \\
\hline Female Teacher & 4.057 & -0.0667 & -3.145 & 0.002 & Significant \\
\hline 12. Confident & & & & & \\
\hline Male Teacher & 4.152 & & & & \\
\hline & & -0.0522 & -2.654 & 0.008 & Significant \\
\hline Female Teacher & 4.204 & & & & \\
\hline
\end{tabular}

\section{Conclusion}

Paired t-test revealed highly a significant difference between the teachers' sex and students' preferences on teachers' personality traits when grouped to male and female. There was a highly significant difference between the teachers' sex and students' preferences of the teachers' personality traits as perceived by the Grade 7 students. Paired t-test showed highly significant difference between the teachers' sex and students' preferences of teachers' 
personality traits such as being fair, democratic, responsive, understanding, kindly, stimulating, original, alert, attractive, and responsible.

\section{Recommendations}

Replication of the study must be done in all subject areas in junior high school to further verify the effects of teachers' sex and personality traits. Studies related to this may also employ a comparison of students' preferences from the private and public junior high schools. School administrators should encourage the exposure teachers on trainings for personality development.

\section{References}

Bandura, A. 1997. Social Learning Theory. General Learning Press, New York.

Bustos, A. S., and S. C. Espiritu. 1996. Psychological, anthropological, and sociological foundations of education. KATHA PUBLISHING CO., INC, Quezon City.

Granitz, N.A., S.K. Koernig, R. Katrin, K.R. Harich. 2009. Now It's Personal: Antecedents and Outcomes of Rapport Between Business Faculty and Their Students. Journal of Marketing Education (31): 52.

Heinstrom, J. 2000. The impact of personality and approaches to learning on information behavior. Information Research, vol. 5 pp.324-342. Department of Information Studies. Abo AKademi University.

Marchbanks, P. 2000. Personality Traits: Elementary School Teachers. University of North Carolina at Chapel Hill.

Ozel, A. 2007. The effect of Turkish geography teacher's personality on his teaching experiences. International Journal of Environmental and Science Education 2(3): 75-78.

Ryan, K. and J.M. Cooper. 1984. $4^{\text {th }}$ Ed. Those Who Can Teach. Houghton Mifflin Company, Boston. Pp. 302-315, 398-406.

Shah, S. R. and U. S. Udgaonkar. 2018. Influence of Gender and Age of Teachers on

Teaching: Students Perspectives. International Journal of Current Microbiology and Applied Sciences. 7(1):24362441,

Spanjaard, D. 2009. The Confluence of Student and Teacher Personality: Towards a Research Agenda. 